${ }^{2}$ Donaldson RM, Rickards AF. Evaluation of drug induced changes in myocardial repolarization using the paced evoked response. $\mathrm{Br}$ Heart $\mathcal{F}$ $1982 ; 48: 381-2$

${ }^{3}$ Vaughan-Williams EM, Hassan MO, Floras JS, Sleight P, Jones JW. Adaptation of hypertensives to treatment with cardioselective and nonselective $\beta$-blockers. Absence of correlation between bradycardia and blood pressure control, and reduction in slope of QT/RR relation. Br Heart $\mathcal{f} 1980 ; 44: 473-87$.

${ }^{4}$ Bruce RA. Exercise testing of patients with coronary heart disease principles and normal standards for evaluation. Ann Clin Res 1971;3 323-32.

${ }^{5}$ Samet P, Castillo C, Bernstein WH. Hemodynamic sequelae of atrial ventricular and sequential atrioventricular pacing in cardiac patients. Am Heart f 1966;72:725-9.

${ }^{6}$ Greenberg B, Chatterjee K, Parmley WW, Werner JA, Holly AN. The influence of left ventricular filling pressure on atrial contribution to cardiac output. Am Heart $\mathcal{f}$ 1979;98:742-51.

7 Koyama T, Nakajima S, Horimoto M. Initial adjustment of cardiac ouput in response to onset of exercise in patients with chronic pacemaking as studied by the measurement of pulmonary blood flow. Am Heart 7 $1976 ; 91: 457-9$.

${ }^{8}$ Goldreyer BN. Physiologic pacing: the role of AV synchrony. (Editorial.) PACE 1982;5:613-5.

${ }^{9}$ Karloff I. Haemodynamic effect of atrial triggered versus fixed rate pacing at rest and during exercise in complete heart block. Acta Med Scand $1975 ; 197: 195-206$

${ }^{10}$ Knudson MB, Amundson DC, Mosharrafa M. Hemodynamic demand pacing. In: Barold SS, Mugica J, eds. The third decade of cardiac pacing. New York: Futura Publishing, 1982:249-64.

11 Kruse I, Arnman K, Conradson TB, Ryden L. A comparison of the acute and long term hemodynamic effects of ventricular inhibited and atrial synchronous ventricular inhibited pacing. Circulation $1981 ; 65: 846-55$.

12 Furman S. Arrhythmias of dual chamber pacemakers. (Editorial.) PACE $1982 ; 5: 469-70$.

${ }^{13}$ Hermansen L, Ekblom B, Saltin B. Cardiac output during submaximal and maximal treadmill and bicycle exercise. $\mathcal{F}$ Appl Physiol 1970;29:82-6.

(Accepted 23 November 1982)

\title{
Consequences of hyponatraemia and hypernatraemia in children with acute diarrhoea in Bangladesh
}

\author{
AZIZ R SAMADI, MOHAMMAD A WAHED, MOHAMMAD R ISLAM, SYED M AHMED
}

\begin{abstract}
A total of 1330 children under 3 years of age who during 1979 had been admitted to the general ward of ICDDR,B Health Complex for diarrhoea with complications were studied retrospectively for the relation between types of dehydration, age, and nutritional state. Of the 1330 children, $276(20.8 \%)$ were hyponatraemic, $969(72.8 \%)$ isonatraemic, and $85(6 \cdot 4 \%)$ hypernatraemic. The incidence of hyponatraemia increased with age, while the incidence of hypernatraemia decreased with age. There was a strong relation between types of dehydration and nutritional state. The incidence of hyponatraemia was directly related to the degree of malnutrition. The case fatality rates for types of dehydration were $10.1 \%$ in hyponatraemia, $3.8 \%$ in isonatraemia, and $1.2 \%$ in hypernatraemia.
\end{abstract}

These observations suggest that hyponatraemia is a serious complication of diarrhoea in Bangladesh.

\section{Introduction}

Dehydration as a result of diarrhoea continues to be a leading cause of death in children, especially in developing countries. ${ }^{1}$ In areas where infant malnutrition is prevalent acute gastroenteritis is common and there is a tendency towards serious complications. ${ }^{2}$ Although in Western countries the various types of dehydration have been studied in small numbers, hypernatraemia is frequently recorded in diarrhoea with a higher mortality rate. ${ }^{3-6}$ The incidence of specific types of dehydration in developing countries where malnutrition is prevalent has not been well documented. Nevertheless, a few reports indicate a higher incidence of hyponatraemia, which is associated with

International Centre for Diarrhoeal Disease Research, Bangladesh (ICDDR,B), GPO Box 128, Dhaka-2, Bangladesh

AZIZ R SAMADI, MD, DPH, scientific programme head, disease transmission

MOHAMMAD A WAHED, BSC, senior research officer

MOHAMMAD R ISLAM, MB, DTM\&H, associate scientist

SYED M AHMED, MB, BS, research trainee (clinical research) malnutrition. ${ }^{7-10}$ Hypernatraemia is reportedly rare in developing countries, possibly because of the high prevalence of malnutrition. ${ }^{7} 8$

We present the results of a retrospective analysis of the types of dehydration in relation to age and nutritional state of children admitted to the general ward of this hospital for diarrhoea with complications.

The ICDDR,B, formerly the Cholera Research Laboratory, is a specialised centre for research in diarrhoeal diseases in the region. The ICDDR,B Health Complex, Dacca, comprises a treatment centre, general ward, and study ward. All cases of diarrhoea with complications are admitted to the general ward for intensive medical care, while uncomplicated cases are treated in an ambulatory treatment centre. Patients for research are admitted to the study ward. The health complex treats about 100000 cases of diarrhoea a year ${ }^{11}$ in patients from the Dacca metropolitan area and beyond.

\section{Materials and methods}

During 1979 a total of 3716 patients with diarrhoea and complications were admitted to the general ward, of whom 1382 were children aged less than 3 years. Of these, 1330 children met our criteria and were accepted into the study. On admission a complete medical history was obtained from the parents of each child and a physical examination performed. Measurement of serum electrolytes, stool microscopy, and stool culture were done along with other routine laboratory examinations. Blood for electrolyte estimations was taken on admission and serum electrolytes measured on an I-L flame photometer. ${ }^{12}$ Our biochemistry laboratory uses a quality control system of samples from the World Health Organisation. ${ }^{11}$ The height and weight of the children were recorded after complete rehydration.

All the children had mild to severe dehydration and were treated intravenously with acetate solution ${ }^{13}$ for initial rehydration followed by either physiological saline or half strength saline plus $5 \%$ dextrose, depending on the serum sodium concentration received from the laboratory within six to eight hours. The types of dehydration were defined as hyponatraemic (serum sodium concentration $<130 \mathrm{mmol}$ $(\mathrm{mEq}) / \mathrm{l}$ ), hypernatraemic (serum sodium concentration $>150 \mathrm{mmol} / \mathrm{l}$ ), and isonatraemic (serum sodium concentration $130-150 \mathrm{mmol} / \mathrm{l}$ ). ${ }^{14} 15$ Nutritional state of the children was assessed by the Gomez classification using weight for age. ${ }^{16}$ Bairagi ${ }^{17}$ confirmed that weight for age is a better screening test for malnutrition than weight for height. Using weight over age (expressed as a percentage) and the standards of the 
National Center for Health Statistics ${ }^{18}$ we calculated normal nutritional state to mild malnutrition as $>75 \%$ of the 50 th percentile, moderate malnutrition as $74-60 \%$ of the 50 th percentile, and severe malnutrition as $<60 \%$ of the 50 th percentile. In assessing the nutritional state of the dead children we used a weight adjusted for the degree of dehydration instead of the post-rehydration weight, since most of the deaths occurred before rehydration was complete.

The distribution of types of dehydration by age groups and nutritional categories was tested by $2 \times \mathrm{k} \chi^{2}$ contingency table. The relative risks of age, nutritional state, and type of dehydration for case fatality were calculated. The relative risks were obtained by arbitrarily defining the first attribute as a reference point and assigning it a relative risk of 1.0 for comparison. The difference in case fatality distribution by age, nutritional state, and type of dehydration was tested by $2 \times k \chi^{2}$ contingency table. The difference between the two serum sodium means was analysed by $Z$ test.



FIG 1-Incidence of different types of dehydration by age.

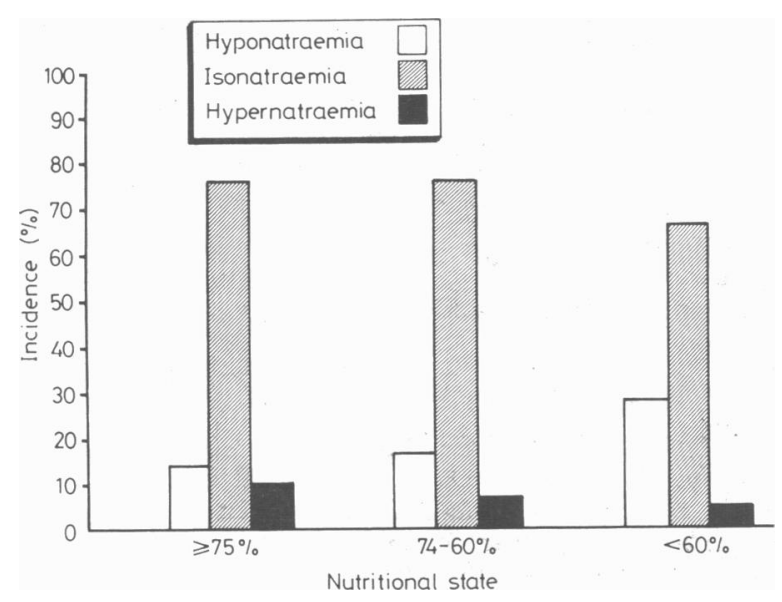

FIG 2-Incidence of types of dehydration by nutritional state.

Risk factors for mortality

\begin{tabular}{|c|c|c|c|c|c|}
\hline Risk factors & $\begin{array}{l}\text { No of } \\
\text { cases }\end{array}$ & $\begin{array}{c}\text { Deaths } \\
(\%)\end{array}$ & $\mathrm{RR}$ & ( $\mathrm{p}$ value) & $\begin{array}{c}\chi^{2} \text { for } \\
\text { linear trend } \\
(p \text { value })\end{array}$ \\
\hline $\begin{array}{l}\text { Age (months) } \\
0-11 \\
12-23 \\
24-35 \\
\text { Weight/age }\end{array}$ & $\begin{array}{l}815 \\
236 \\
279\end{array}$ & $\begin{array}{l}4 \cdot 9 \\
3 \cdot 0 \\
6 \cdot 8\end{array}$ & $\left.\begin{array}{l}1 \cdot 0 \\
0 \cdot 6 \\
1 \cdot 4\end{array}\right)$ & $4 \cdot 0$ (NS) & $0.8(\mathrm{NS})$ \\
\hline $\begin{array}{l}\geqslant 75 \\
74-60 \\
<60\end{array}$ & $\begin{array}{l}275 \\
478 \\
577\end{array}$ & $\begin{array}{l}5 \cdot 4 \\
4 \cdot 2 \\
5 \cdot 4\end{array}$ & $\left.\begin{array}{l}1 \cdot 0 \\
0.8 \\
1 \cdot 0\end{array}\right)$ & $0.4(\mathrm{NS})$ & $0.02(\mathrm{NS})$ \\
\hline $\begin{array}{l}\text { Serum sodium }(\mathrm{mmol} / \mathrm{l}) \\
\quad<130 \\
130-150 \\
>150\end{array}$ & $\begin{array}{r}1) \\
276 \\
969 \\
85\end{array}$ & $\begin{array}{r}10 \cdot 1 \\
3 \cdot 8 \\
1 \cdot 2\end{array}$ & $\begin{array}{l}1 \cdot 0 \\
0.4 \\
0 \cdot 1\end{array}$ & $21.00(-0.0001)$ & $19.51(.0 .0001)$ \\
\hline
\end{tabular}

$\mathbf{R} \mathbf{R}=$ Relative risk

NS $=$ Not significan

Conversion: SI to traditional units-Sodium: $1 \mathrm{mmol} / 1=1 \mathrm{mEq} /$.

\section{Results}

Of the 1330 children, $276(20 \cdot 8 \%)$ were hyponatraemic, $969(72.8 \%)$ isonatraemic, and $85(6.4 \%)$ hypernatraemic. The mean serum sodium concentrations $(\mathrm{SD})$ in the three groups were $124 \cdot 6+4 \cdot 2$ $\mathrm{mmol}(\mathrm{mEq}) / 1,137 \cdot 2 \div 4.8 \mathrm{mmol} / 1$, and $156 \cdot 1 \div 6.4 \mathrm{mmol} / 1$, respectively. Figure 1 shows the incidences of the different types of dehydration at various ages. The difference in incidence of isonatraemia among the different age groups was not significant ( $\chi^{2}$ test: $\left.2 \mathrm{df}=0.07, \mathrm{p} 0.05\right)$. The difference in incidence of hyponatraemia among the different age groups was significant $\left(\chi^{2}: 2 \mathrm{df}=8 \cdot 12, \mathrm{p}<0.02\right)$, and the incidence increased with age $\left(\gamma^{2}\right.$ for linear trend $\left.=8.11, \mathrm{p}<0.01\right)$. The difference in distribution of hypernatraemia among the age groups was significant $\left(x^{2}: 2 \mathrm{df}=25 \cdot 78, \mathrm{p}<0.001\right)$, and the incidence decreased with increasing age $\left(\chi^{2}\right.$ for linear trend $\left.=25 \cdot 70, p<0.001\right)$

The mean serum sodium concentrations ( $t$ SD) in the children with a normal nutritional state or mild malnutrition $(n=275)$, moderate malnutrition $(n=478)$, and severe malnutrition $(n=577)$ were $138.0 \pm 8.9 \mathrm{mmol}, 136.5 \div 8.8 \mathrm{mmol}$, and $134.2 \div 3.5 \mathrm{mmol} / \mathrm{l}$, respectively. The difference in mean serum sodium concentrations between the mildly malnourished and moderately malnourished groups was significant $(Z=2 \cdot 12, \mathrm{p}<0.05)$; the difference between the moderately and severely malnourished groups was also significant $(Z=4.40, p<0.001)$. Figure 2 shows the incidences of types of dehydration according to nutritional state. The difference in distri- o bution of isonatraemia by nutritional categories was significant $\left(\chi^{2}\right.$ : $2 \mathrm{df}=16 \cdot 23, \mathrm{p}<0.001)$. Isonatraemia was less frequent in severely malnourished children than in the moderately or mildly malnourished group $\left(x^{2}=\mathrm{p}<0.001\right)$. The difference in incidence of hyponatraemia by nutritional categories was significant $\left(\chi^{2}: 2 \mathrm{df}=35.47, \mathrm{p}<0.001\right)$, and the incidence increased with the degree of malnutrition $\left(\chi^{2}\right.$ for linear trend $=31 \cdot 13, p<0.001)$. The difference in distribution of hypernatraemia among the nutritional categories was significant $\left(\chi^{2}\right.$ : $2 \mathrm{df}=7.59, \mathrm{p}<0.02)$, and the incidence decreased with increasing degree of malnutrition ( $\chi^{2}$ for linear trend $=7 \cdot 95, \mathrm{p}<0.01$ ).

The table shows the risk factors for mortality. There was a strong association between case fatality and serum sodium value $(\mathrm{p}<0.0001)$. Also case fatality and serum sodium concentration followed a linear trend $(\mathrm{p}<0.0001)$. The mortality rate was $10.1 \%$ in hyponatraemia, $3.8 \%$ in isonatraemia, and $1.2 \%$ in hypernatraemia (one child with a serum sodium concentration of $152 \mathrm{mmol} / 1$ ). There was no association between mortality and age or nutritional state $(p-0.05)$.

Data on the dietary patterns of these children before admission were not complete enough for further correlations. Aetiology, complications, and more details on case fatality will be reported separately.

\section{Discussion}

Our findings show that hypernatraemia is not a problem in Dacca but that hyponatraemia is a serious problem. Finberg reported that hypernatraemia accounts for $20-25 \%$ of diarrhoeal diseases in patients admitted to hospitals in North America with a high mortality rate, ${ }^{4}$ while we found hypernatraemia in only $6.4 \%$ of children admitted to hospital with a $1.2 \%$ case fatality rate. In contrast to Western countries, hyponatraemia was more prevalent in Bangladesh with a high incidence and high case fatality rate in the children admitted to the hospital. This is in line with earlier reports. ${ }^{7-9}$

The incidences of hypernatraemia and hyponatraemia were $D$ related to age. The incidence of hypernatraemia decreased with increasing age, while the incidence of hyponatraemia increased $N$ with age. These trends in incidences of hypernatraemic and N hyponatraemic dehydration in relation to age followed the growth pattern of these children. Khan $e t$ al $^{10}$ showed that the growth of children in Meheran (Bangladesh) was satisfactory for the first four months of life, but that subsequently the gap between the Boston standard and the growth of these children gradually widened. This may explain the high incidence of hyponatraemia and low incidence of hypernatraemia in children over 1 year of age. These findings suggest that poor nutritional state is a risk factor for development of hyponatraemia.

We also observed a significant relation between serum sodium concentration and nutritional state. The mean serum sodium concentration irrespective of type of dehydration was lower in severe malnutrition than in moderate malnutrition and $\bar{c}$ lower in moderate malnutrition than in the normal nutritional $\stackrel{\rightleftharpoons}{\rightleftharpoons}$ 
state or mild malnutrition. The incidence of hyponatraemia was directly related to the degree of malnutrition. In contrast, the incidence of hypernatraemia was inversely related to the degree of malnutrition. These findings confirm our belief that moderately and severely malnourished children are more prone to develop hyponatraemic than hypernatraemic dehydration. The explanation for these findings may be that the poor reserves of electrolytes and other nutrients in malnourished children cannot compensate for accumulated losses of sodium.

In examining the relative risk of age, nutritional state, and types of dehydration for case fatality, case fatality was related to serum sodium concentrations rather than age group or nutritional state. In hyponatraemia case fatality was 10 times higher than in hypernatraemia and 2.5 times greater than in isonatraemia. Although the incidence of hyponatraemia was related to age and degree of malnutrition, case fatality was not associated with these factors. The high mortality in hyponatraemic dehydration may be due to vascular volume, which is less well preserved in hyponatraemic dehydration than in hypernatraemic or isonatraemic dehydration. This may explain the high mortality in hyponatraemic and low mortality in hypernatraemic dehydration.

Although our knowledge about the dietary patterns of these children in relation to types of dehydration is scanty, the results of this study document the high incidence and high case fatality rate of hyponatraemic dehydration. Thus in contrast to hypernatraemia, hyponatraemia is a serious complication of diarrhoea among children admitted to hospital in Bangladesh.

We are grateful to Dr W B Greenough III, director of ICDDR, B, for his critical review of the manuscript. We also thank Mrs $S$ Chowdhury and Mrs P Mahamud for secretarial work.

\section{References}

' Puffer RR, Serrano CV. Patterns of mortality in childhood: report of the inter-American investigation of mortality in childhood. Washington, DC:
Pan American Health Organisation, 1973. (Scientific publication No 262.)

James JW. Longitudinal study of the morbidity of diarrheal and respiratory infections in malnourished children. Am $\mathcal{F}$ Clin Nutr 1972;25:690-4.

${ }^{3}$ Harrison HE, Finberg L. Hypernatremic dehydration. Pediatr Clin North Am 1964;11:955-61.

${ }^{4}$ Finberg L. Hypernatremic dehydration. In: Handbook and abstracts of the international conference on infant nutrition and diarrheal disease and workshop on postgraduate pediatric education. Kuala Lumpur: Department of Pediatrics, University of Malaya, 1979:93.

Ironside AG, Tuxford AF, Heyworth B. A survey of infantile gastroenteritis. Br Med F 1970;iii:20-4.

6 Taitz LS, Byers HD. High calorie osmolar feeding and hypertonic dehydration. Arch Dis Child 1972;47:257-60.

Udani PM, Shah PM, Mukerji S, et al. Trends in the treatment of acute diarrhoeas in infancy. Indian Pediatr 1968;5:1-16.

"Wharton BA. Gastroenterological problems in children of developing countries. In: Anderson CM, Burke V, eds. Paediatric gastroenterology. Oxford: Blackwell, 1975:574.

${ }^{y}$ Garrow JS, Smith R, Ward EE. Electrolyte metabolism in severe infantile malnutrition. Oxford: Pergamon Press, 1968:50.

${ }^{0}$ Kumar V, Mohan VM, Kumar L. Fluid and electrolyte problems in acute gastroenteritis-correlation with nutritional status. Indian Pediatr $1977 ; \mathbf{1 4}: 449-53$

11 Beckett J, Mecartney J, eds. Annual report. International Centre for Diarrhoeal Disease Research, Bangladesh. Dacca: ICDDR,B, 1980.

12. Haven GT, Haven MC. Serum sodium measurement by manual and on-line dilutions. Clin Chem 1973;19:791.

13 Cash RA, Toha KMM, Nalin DR, Huq Z, Phillips RA. Acetate in the correction of acidosis secondary to diarrhoea. Lancet 1969;ii:302-3.

14 Vaughan VC III, McKay RJ, Behrman RE, eds. Nelson textbook of pediatrics. 11th ed. Philadelphia: Saunders, 1979:288-9.

15 Walker-Smith J. Diseases of the small intestine in childhood. 2nd ed. London: Pitman, 1979:217-9.

16 Gomez F, Calvan S, Frank J, Gravioto R, Chaves R, Vazquez J. Mortality in second and third degree malnutrition. 7 Trop Pediatr 1956;2:77-83.

17 Bairagi R. On validity of some anthropometric indicators as predictors of mortality. Am f Clin Nutr $1981 ; 34: 2592-4$.

18 US Department of Health, Education, and Welfare. NCHS growth curves for children: birth-18 years. Hyattsville, Md: National Center for Health Statistics, 1977. (DHEW publication No (PHS) 78-1650, series 11, No 165.)

${ }^{19}$ Khan M, Curlin GR, Chakraborty J. Growth and development studies rural Meheran Comilla. Bangladesh Medical fournal 1979;7:74-90.

(Accepted 24 November 1982)

\title{
Accuracy and value of the Hemoccult test in symptomatic patients
}

\author{
ROGER J LEICESTER, ANTONIA LIGHTFOOT, JUDITH MILLAR, DUNCAN G COLIN-JONES, \\ RICHARD H HUNT
}

\begin{abstract}
Hemoccult faecal occult blood testing is widely advocated as a screening test for colorectal cancer but few studies have shown its correlation with conventional methods of investigation for colorectal disease.
\end{abstract}

Department of Gastroenterology, Royal Naval Hospital, Haslar, Gosport, Hants PO12 2AA

ROGER J LEICESTER, FRCS, surgeon lieutenant-commander, Royal Navy consultant surgeon

ANTONIA LIGHTFOOT, research assistant

JUDITH MILLAR, MSR, research assistant

RICHARD H HUNT, FRCP, surgeon commander, Royal Navy consultant physician and gastroenterologist (now professor and head, division of gastroenterology, McMaster University, Hamilton, Ontario)

Department of Gastroenterology, Queen Alexandra's Hospital, Cosham, Portsmouth, Hants PO6 3LY

DUNCAN G COLIN-JONES, FRCP, consultant physician
In a prospective study of 802 symptomatic patients with suspected colorectal disease there was good patient compliance $(92.5 \%)$ and a high specificity for colorectal cancer $(85.4 \%)$. The false positive rate was $8.6 \%$ (12 of 140 patients with positive results), and while the test result was positive in 22 of 26 colonic cancers the false negative rate for rectal cancer $(\mathbf{4 5} \cdot 4 \%)$ should not detract from its value as a screening test if proper digital anorectal and proctosigmoidoscopic examination are widely practised.

A positive Hemoccult test result is a useful indicator for the need to proceed to full colorectal investigation, including colonoscopy.

\section{Introduction}

The Hemoccult test has been widely advocated to screen for colorectal cancer ${ }^{12}$ but no prospective studies have compared its efficacy with conventional investigation nor examined its value 